\title{
Rheo-diecasting of recycled AZ91D magnesium alloy
}

\author{
G. Liu, Y. Wang and Z. Fan \\ BCAST, Brunel University, Uxbridge UB8 3PH, UK
}

\begin{abstract}
Magnesium recycling has become more important in today's environmentally aware society. To prompt the usage of recycled magnesium scrap and further improve casting structure and properties, a novel physical approach, the rheo-diecasting process (RDC), has been applied in the present study to deal with AZ91D Mg-alloy directly from die-casting scrap. The experimental results show that the RDC process can be used to produce recycled AZ91D alloy with fine and uniform microstructure and a very low level of porosity. The intermetallic compounds containing the impurity elements were of fine and of spherical morphology, distributed uniformly in the alloy matrix. No oxide particle clusters or oxide films were found in the RDC microstructure. The tensile properties of the recycled AZ91D alloy were comparable to those produced by RDC from the primary alloy ingots., and much better than those produced by conventional High Pressure Die Casting (HPDC).
\end{abstract}

Keywords: Rheo-diecasting, AZ91D Mg alloy, recycling, high pressure die casting.

\section{Introduction}

Magnesium alloys, the lightest of all structural metallic materials, find increasing applications in the automotive industry for vehicle weight reduction [1]. This means an increase in Mg-alloy scrap from both manufacturing sources (new scrap) and end-of-life vehicles (old scrap). In typical magnesium die-casting operations, only around 50\% of the metal ends up as finished product, and the remaining $50 \%$ of magnesium alloy is accumulated as scrap [2]. However, metals, such as aluminium and magnesium, can be recycled repeatedly without loss of their inherent properties. Therefore, recycling Mg-alloy scrap is becoming an important technical and economic challenge. The more recycled material is used, the lower the energy consumption and, therefore, a reduction in environmental damage. A major barrier to the recycling of $\mathrm{Mg}$-alloys is the existence of substantial amounts of inclusions and impurity elements in the scrap (both new and old). The former causes severe loss of ductility and strength, and the latter significantly reduces the corrosion resistance. The major challenges in reprocessing light alloy scrap are dealing with the increased inclusions and impurity elements. Conventional wisdom is to reduce the amount of such inclusions and impurities by a chemical approach [3-5], e.g., flux or fluxless refining, and hydrometallurgy processes. However, there are still some problems in these recycling technologies, such as process complexity, low productivity and high-energy consumption. Therefore, there is a growing need for more effective recycling processes for $\mathrm{Mg}$-alloy scrap. In recent years, semisolid metal processing (SSM) has been shown to possess a number of technological advantages over traditional casting processes. It has proved to be particularly suitable for light alloy components with improved mechanical performance [6,7]. Among these SSM processes, the rheodiecasting process (RDC), recently developed by BCAST at Brunel University, is a promising technology in terms of process flexibility, component integrity, microstructural homogeneity and cost-effectiveness [8-10]. The aim of the present study is to investigate the feasibility of using the RDC process as an enabling technology for direct recycling of magnesium alloy scrap.

\section{Experimental}

The primary AZ91D magnesium alloy was provided by MEL (Magnesium Electron, Manchester, UK). The chemical composition of the material as received was $8.6 \% \mathrm{Al}$, $0.67 \% \mathrm{Zn}, \quad 0.22 \% \mathrm{Mn}, \quad 0.03 \% \mathrm{Si}, \quad 0.01 \% \mathrm{Cu}, \quad 0.002 \% \mathrm{Fe}$, $0.0007 \% \mathrm{Ni}$ and $0.001 \% \mathrm{Be}$ (all in wt.\%). The starting materials used in the present study were 'new' AZ91D Mgalloy mixed with different weight percentages of recycled AZ91D die-casting scrap i.e. $50 \%$ and $100 \%$, respectively. The recycled AZ91D die-casting scrap include biscuits and gates $(70 \%)$, runners $(20 \%)$, overflows $(9 \%)$, and dross $(1 \%)$. The weighed AZ91D alloy was melted in a steel crucible of capacity $15 \mathrm{~kg}$, using an electrical resistance furnace at a holding temperature of $675^{\circ} \mathrm{C}$. To avoid oxidation of the molten $\mathrm{Mg}$-alloy, a protective gas mixture of $\mathrm{N}_{2}$ containing $\mathrm{SF}_{6}$ was used in both the melting and the subsequent $\mathrm{RDC}$ process. The RDC equipment consists of two basic functional units: a twin-screw slurry maker (TSSM) and a standard cold chamber high-pressure die-casting (HPDC) machine. The TSSM has a pair of screws rotating inside a barrel. The fluid flow inside the slurry maker is characterised by high shear rate and high intensity of turbulence. In the 

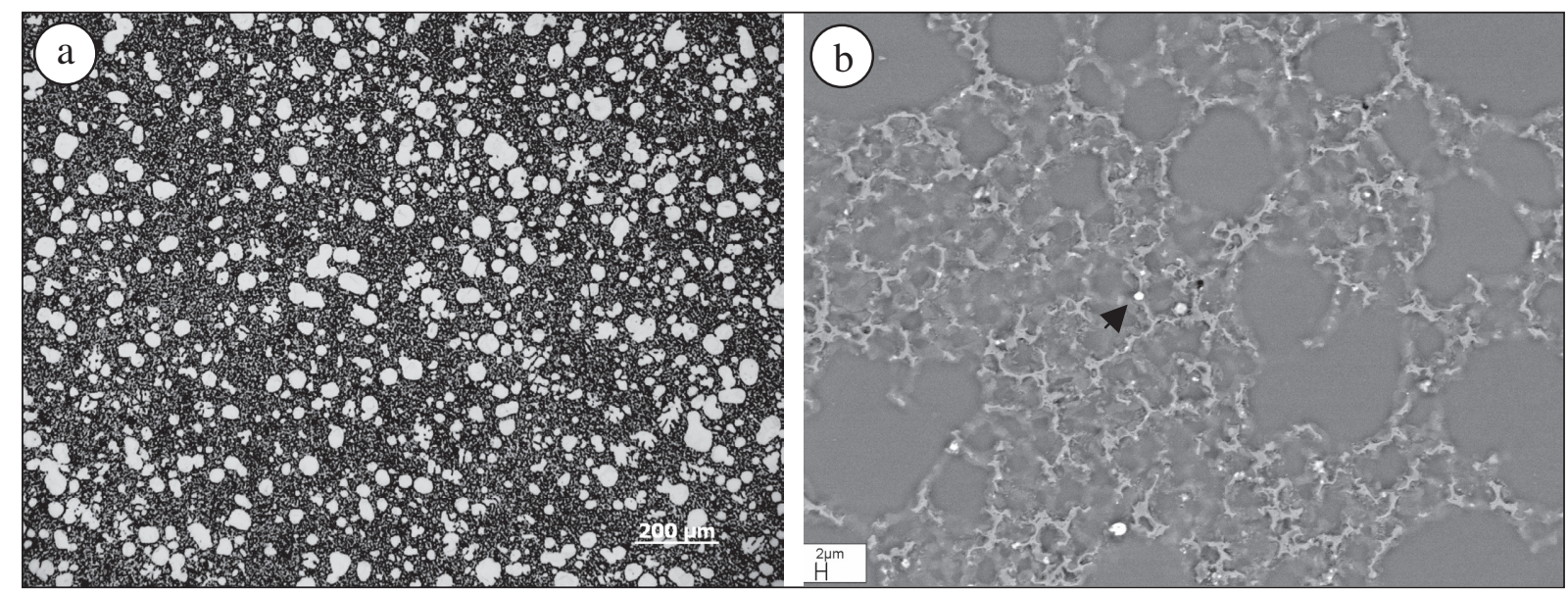

Figure 1: Typical RDC microstructure from 100\% AZ91D die-casting scrap. (a) is a general view and (b) is a SEM micrograph.

present study, the rotation speed of the TSSM was fixed at $800 \mathrm{rpm}$, and the shearing time at 30 seconds. A 280 -ton standard HPDC machine was used to produce standard tensile test samples. For all the experiments in this investigation, the die temperature was kept constant at $235^{\circ} \mathrm{C}$. The dimensions of the tensile test samples were $6 \mathrm{~mm}$ in gauge diameter, $60 \mathrm{~mm}$ in gauge length and $150 \mathrm{~mm}$ in total length. A detailed description of the RDC process can be found elsewhere [11]. An optimised T4, T5 and T6 heat treatment [12] (solution at $413^{\circ} \mathrm{C}$ for $5 \mathrm{~h}$ then quenching in water, $\mathrm{T} 4$, and then aging at $216^{\circ} \mathrm{C}$ for $5.5 \mathrm{~h}, \mathrm{~T} 6 . \mathrm{T} 5$ was treated at $216^{\circ} \mathrm{C}$ for $5 \mathrm{~h}$ ), was carried out for evaluation of the mechanical properties for heat-treated RDC AZ91D alloy. The metallographic specimens used for OM (Optical Microscope) and SEM (Scanning Electron Microscope) investigations were prepared by the standard technique: grinding with $\mathrm{SiC}$ abrasive paper and polishing with an $\mathrm{Al}_{2} \mathrm{O}_{3}$ suspension solution, followed by etching in the relevant etchant. The volume fraction of primary $\alpha-\mathrm{Mg}$ phase and defects were measured using an AxioVision image analysis system. The chemical composition analysis was conducted on a WAS Foundry Master. The evaluation of mechanical properties under as-cast and various heattreated states was carried out at room temperature on a Lloyd Instrument EZ50 tensile test machine, with a strain rate of $6.7 \times 10^{-4} \mathrm{~s}^{-1}$.

\section{Microstructural characteristics of the RDC recycled AZ91D Mg-alloy}

Figure 1 shows the microstructure of the RDC AZ91D Mg-alloy produced from 100\% recycled AZ91D scrap. It indicates that the RDC processed materials exhibit fine and spherical primary $\alpha$-phase particles with a uniform distribution. This is typical of semi-solid RDC microstructures. Solidification in the RDC process has been identified as having two distinct stages, i.e. primary and secondary solidification [13]. In Figure 1a, the relatively large and spherical particles are primary $\alpha-\mathrm{Mg}$ phase produced inside the twin-screw slurry maker under high shear rate and high intensity of turbulence; the average particle size is $37.6 \mu \mathrm{m}$ and the volume fraction is $19.5 \%$. The general microstructural investigation suggests that the typical microstructure of RDC AZ91D Mg-alloy is dominated by primary solidification in the Twin-Screw slurry maker. In addition, the total porosity measured in samples produced from RDC new AZ91D and RDC 100\% recycled alloy was much less (0.3 vol.\%) than for conventional HPDC alloy (>2 vol.\% $[14,15])$. Secondary solidification began when the semisolid slurry was transferred to the shot sleeve, while a partial volume fraction of the primary $\alpha-\mathrm{Mg}$ phase was produced in the remaining liquid. Such particles usually have a dendritic morphology and can be found randomly in the solidification microstructure, as shown in Figure 1a. Other remaining liquid in the semi-solid slurry finally solidified in the die cavity under a high pressure and high cooling rate, and the resulting microstructure is of extremely fine $\alpha-\mathrm{Mg}$ particles (less than $10 \mu \mathrm{m}$ ) mixed with the $\mathrm{Mg}_{17} \mathrm{Al}_{12} \beta$-phase. Figure $1 \mathrm{~b}$ shows a more detailed SEM microstructure on which EDS (energy dispersive spectroscopy) concentrated on the intermetallic phases (arrowed bright particles) existing in the RDC recycled AZ91D alloy samples. The intermetallic particles show a well-dispersed distribution in the liquid matrix, and are extremely fine (less than $3 \mu \mathrm{m}$ in average size). In the extensive SEM/EDS analysis, difficulty has been encountered in finding evidence of any coarse oxide clusters or oxide films in the recycled alloy. This is a significant advantage compared to conventional die-casting technology in which impurity inclusions were found to be non-uniformly distributed and usually presented oxide films when the alloy was contaminated. Further EDS analysis found that most of the bright particles in the RDC microstructure contain aluminium, manganese and oxygen. The oxygen is preferentially associated with elements $\mathrm{Mn}$ in the form of spherical compounds. Isolated $\mathrm{Al}_{8} \mathrm{Mn}_{5}$ particles of about 1 to $3 \mu \mathrm{m}$ in diameter were frequently observed, and some of the bright particles contained little iron. In the rheo-diecasting process, the intensive forced convection generated by the twin-screw mechanism not only promotes the formation of the harmless spherical morphology of non-metallic and metallic impurities, but also improves their distribution through the microstructure. As shown in Figures $1 \mathrm{a}$ and $\mathrm{b}$, they are extremely fine and well dispersed. Oxide films or coarse clusters, if there are any, will be broken up, spheroidised and dispersed by the extensive shearing. 


\section{Chemical variations of the recycled AZ91D Mg-alloy}

There are four main alloying elements (Al, $\mathrm{Zn}, \mathrm{Mn}$, and $\mathrm{Be}$ ) and four detectable impurities $(\mathrm{Si}, \mathrm{Fe}, \mathrm{Cu}$, and $\mathrm{Ni}$ ) in the AZ91D Mg-alloy, and each element varies over a certain concentration range. Table 1 shows the chemical compositions of different AZ91D materials after melting and rheodiecasting process. It can be seen that for both alloying elements and impurity elements (except Fe), slight changes in compositions occurred after melting of the primary alloy, and there were no obvious changes in compositions after RDC processing with different starting materials. After melting of the primary alloy ingot, $\mathrm{Al}$ content increased by $0.31 \mathrm{wt} \%$ and $\mathrm{Zn}$ content decreased by $0.04 \mathrm{wt} \%$. It should be noted that all these changes in composition are well within the alloy specification [16].

The iron concentration of the RDC recycled AZ91D alloy is slightly higher than that in the primary alloy. However, it is important to point out that the RDC process does not increase Fe content in the final RDC castings compared with former melting stage. As shown in Table 1, for the primary alloy, Fe content increased from $38 \mathrm{ppm}$ in the ingot to $40 \mathrm{ppm}$ in the molten alloy and $41 \mathrm{ppm}$ in the RDC sample; while for the scrap alloy, Fe content showed no change after the RDC process. In general, $\mathrm{Fe}$ is picked up mainly from the use of iron equipment during melting.
Table 1 also shows that, after RDC of the AZ91D Mg-alloy, there was no obvious change in chemical concentrations for other impurity elements compared to after melting.

\section{Mechanical properties of the RDC recycled AZ91D Mg-alloy}

Table 2 gives the tensile properties of the RDC recycled AZ91D alloy under various processing conditions. The mechanical properties for the primary alloy prepared under the same conditions are also provided. It was found that both yield strength (YS) and ultimate tensile strength (UTS), for the alloy recycled from different weight percentages of scrap, are comparable with those of the primary AZ91D alloy.

However, recycling of the AZ91D scrap does cause a decrease in ductility, but the reduction is comparably small, being $0.5 \%$ compared with that of the primary alloy. The RDC alloy recycled from $100 \%$ scrap maintains a considerably high elongation property of $6.4 \%$ in the as-cast state, which is much higher than the 3 to $3.3 \%$ achieved by the normal HPDC process using primary alloy ingot [16,17]. The properties of magnesium alloy can be considerably affected by the incorporation of impurities within the recycled alloys. These chemical impurities can lead to a severe reduction in ductility. A ductility decrease of up to $50 \%$ has been found in some magnesium alloy systems [3].

Table 1: Chemical compositions of AZ91D Mg alloy under different processing conditions (in wt.\%).

\begin{tabular}{|c|c|c|c|c|c|c|c|c|}
\hline Element & $\mathrm{Al}$ & $\mathrm{Zn}$ & $\mathrm{Si}$ & $\mathrm{Cu}$ & $\mathrm{Mn}$ & $\mathrm{Fe}$ & $\mathrm{Ni}$ & $\mathrm{Be}$ \\
\hline $\begin{array}{l}\text { Primary } \\
\text { Ingot }\end{array}$ & $\begin{array}{c}8.38 \\
\pm 0.75\end{array}$ & $\begin{array}{c}0.78 \\
\pm 0.016\end{array}$ & $\begin{array}{c}0.0425 \\
\pm 0.0006\end{array}$ & $\begin{array}{c}0.041 \\
\pm 0.002\end{array}$ & $\begin{array}{c}0.456 \\
\pm 0.032\end{array}$ & $\begin{array}{c}0.0038 \\
\pm 0.0001\end{array}$ & $\begin{array}{c}0.0030 \\
\pm 0.0000\end{array}$ & $\begin{array}{c}0.0011 \\
\pm 0.0001\end{array}$ \\
\hline $\begin{array}{l}\text { Primary } \\
\text { Molten }\end{array}$ & $\begin{array}{c}8.69 \\
\pm 0.78\end{array}$ & $\begin{array}{c}0.74 \\
\pm 0.021\end{array}$ & $\begin{array}{c}0.0428 \\
\pm 0.0005\end{array}$ & $\begin{array}{c}0.046 \\
\pm 0.002\end{array}$ & $\begin{array}{c}0.473 \\
\pm 0.023\end{array}$ & $\begin{array}{c}0.0040 \\
\pm 0.0001\end{array}$ & $\begin{array}{c}0.0040 \\
\pm 0.0000\end{array}$ & $\begin{array}{c}0.0010 \\
\pm 0.0001\end{array}$ \\
\hline $\begin{array}{l}50 \% \text { scrap } \\
\text { Molten }\end{array}$ & $\begin{array}{c}8.75 \\
\pm 0.40\end{array}$ & $\begin{array}{c}0.76 \\
\pm 0.015\end{array}$ & $\begin{array}{c}0.0428 \\
\pm 0.0005\end{array}$ & $\begin{array}{c}0.046 \\
\pm 0.003\end{array}$ & $\begin{array}{c}0.476 \\
\pm 0.016\end{array}$ & $\begin{array}{c}0.0042 \\
\pm 0.0001\end{array}$ & $\begin{array}{c}0.0038 \\
\pm 0.0005\end{array}$ & $\begin{array}{c}0.0010 \\
\pm 0.0000\end{array}$ \\
\hline $\begin{array}{l}100 \% \text { scrap } \\
\text { Molten }\end{array}$ & $\begin{array}{c}8.76 \\
\pm 0.46\end{array}$ & $\begin{array}{c}0.75 \\
\pm 0.015\end{array}$ & $\begin{array}{c}0.0432 \\
\pm 0.0005\end{array}$ & $\begin{array}{c}0.048 \\
\pm 0.002\end{array}$ & $\begin{array}{c}0.482 \\
\pm 0.015\end{array}$ & $\begin{array}{c}0.0043 \\
\pm 0.0001\end{array}$ & $\begin{array}{c}0.0040 \\
\pm 0.0000\end{array}$ & $\begin{array}{c}0.0011 \\
\pm 0.0001\end{array}$ \\
\hline $\begin{array}{l}\text { Primary } \\
\text { RDC }\end{array}$ & $\begin{array}{c}8.66 \\
\pm 0.31\end{array}$ & $\begin{array}{c}0.77 \\
\pm 0.02\end{array}$ & $\begin{array}{c}0.0429 \\
\pm 0.0007\end{array}$ & $\begin{array}{c}0.047 \\
\pm 0.003\end{array}$ & $\begin{array}{c}0.472 \\
\pm 0.021\end{array}$ & $\begin{array}{c}0.0041 \\
\pm 0.0001\end{array}$ & $\begin{array}{c}0.0038 \\
\pm 0.0005\end{array}$ & $\begin{array}{c}0.0010 \\
\pm 0.0001\end{array}$ \\
\hline $\begin{array}{l}50 \% \text { scrap } \\
\text { RDC }\end{array}$ & $\begin{array}{c}8.8 \\
\pm 0.27\end{array}$ & $\begin{array}{c}0.75 \\
\pm 0.036\end{array}$ & $\begin{array}{c}0.0440 \\
\pm 0.0019\end{array}$ & $\begin{array}{c}0.047 \\
\pm 0.007\end{array}$ & $\begin{array}{c}0.471 \\
\pm 0.020\end{array}$ & $\begin{array}{c}0.0042 \\
\pm 0.0001\end{array}$ & $\begin{array}{c}0.0045 \\
\pm 0.0005\end{array}$ & $\begin{array}{c}0.0010 \\
\pm 0.0001\end{array}$ \\
\hline $\begin{array}{l}\text { I00\% scrap } \\
\text { RDC }\end{array}$ & $\begin{array}{c}8.83 \\
\pm 0.34\end{array}$ & $\begin{array}{c}0.75 \\
\pm 0.02\end{array}$ & $\begin{array}{c}0.0452 \\
\pm 0.0016\end{array}$ & $\begin{array}{c}0.050 \\
\pm 0.006\end{array}$ & $\begin{array}{c}0.475 \\
\pm 0.012\end{array}$ & $\begin{array}{c}0.0042 \\
\pm 0.0001\end{array}$ & $\begin{array}{c}0.0045 \\
\pm 0.0005\end{array}$ & $\begin{array}{c}0.0010 \\
\pm 0.0000\end{array}$ \\
\hline
\end{tabular}

The \pm values indicated are standard deviations of the measurements.

Table 2: Tensile properties of the RDC AZ91D alloy processed under different conditions.

\begin{tabular}{|c|c|c|c|c|}
\hline \multicolumn{2}{|c|}{ Sample conditions } & YS (MPa) & UTS (MPa) & Elongation (\%) \\
\hline $\begin{array}{l}\text { RDC } \\
\text { As-cast }\end{array}$ & $\begin{array}{l}\text { Primary AZ9ID } \\
50 \% \text { Scrap } \\
\text { I00\% Scrap }\end{array}$ & $\begin{array}{l}|39.8 \pm 4 .| \\
\mid 39.6 \pm 2.3 \\
\mid 39.6 \pm 2.7\end{array}$ & $\begin{array}{l}250.1 \pm 7.6 \\
249.3 \pm 8.2 \\
249.2 \pm 6.6\end{array}$ & $\begin{array}{l}6.86 \pm 0.68 \\
6.67 \pm 0.92 \\
6.39 \pm 0.59\end{array}$ \\
\hline $\begin{array}{l}\text { RDC } \\
+\mathrm{T} 4\end{array}$ & $\begin{array}{l}\text { Primary AZ9ID } \\
\text { I00\% Scrap }\end{array}$ & $\begin{array}{l}96.9 \pm 4.0 \\
95.9 \pm 2.1\end{array}$ & $\begin{array}{c}263.8 \pm 10.7 \\
260.9 \pm 9.0\end{array}$ & $\begin{array}{l}11.61 \pm 1.57 \\
\mid 1.33 \pm 1.32\end{array}$ \\
\hline $\begin{array}{l}\mathrm{RDC} \\
+\mathrm{T} 5\end{array}$ & $\begin{array}{l}\text { Primary AZ9ID } \\
\text { I00\% Scrap }\end{array}$ & $\begin{array}{l}142.8 \pm 1.9 \\
144.9 \pm 1.3\end{array}$ & $\begin{array}{l}242.4 \pm 8.9 \\
243.0 \pm 7.3\end{array}$ & $\begin{array}{l}5.27 \pm 0.51 \\
4.54 \pm 0.53\end{array}$ \\
\hline $\begin{array}{l}\mathrm{RDC} \\
+\mathrm{T} 6\end{array}$ & $\begin{array}{l}\text { Primary AZ9ID } \\
\text { I00\% Scrap }\end{array}$ & $\begin{array}{l}134.0 \pm 6.0 \\
\mid 34.1 \pm 6.4\end{array}$ & $\begin{array}{c}259.2 \pm 8.5 \\
260.6 \pm 12.6\end{array}$ & $\begin{array}{l}5.59 \pm 0.82 \\
4.76 \pm 0.88\end{array}$ \\
\hline
\end{tabular}




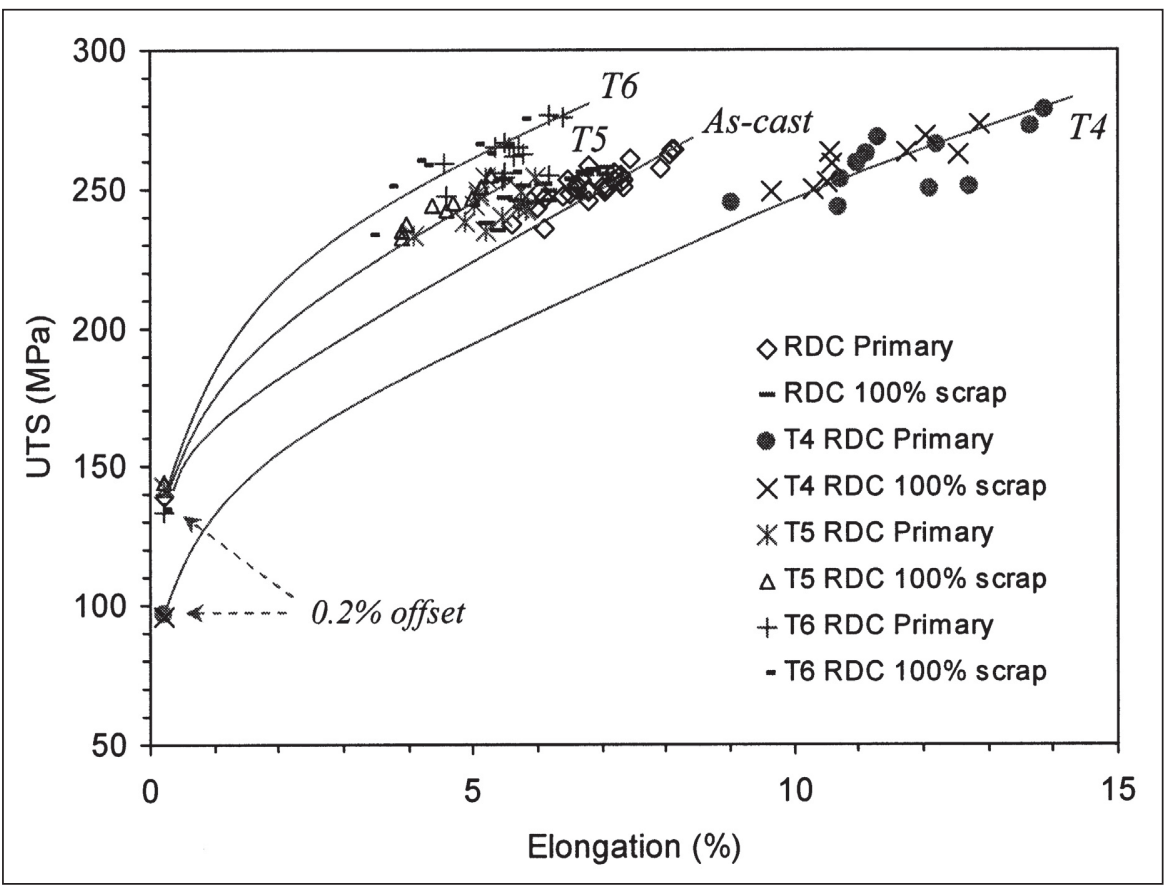

Figure 2: Stress-strain curves for RDC AZ91D alloy obtained under different processing conditions.
Therefore, the quality of recycled magnesium alloys has to be controlled carefully through chemical refining before die-casting. In this study, however, there is no significant reduction in ductility for the recycled alloy in comparison with the primary RDC alloy. It is also interesting to note that the yield strength and UTS of the recycled alloy are essentially the same as for the primary alloy. This superb combination of strength and ductility can be attributed to the fine, dispersed intermetallic compounds, the uniformly distributed fine primary and secondary $\alpha$-phase microstructures and the much reduced porosity level produced by the RDC process, all of which promote uniform deformation, hence eliminating stress concentration.

Figure 2 shows strain-stress curves for the RDC AZ91D alloy after different heat treatments. It can be seen that the T6 treatment improves the UTS significantly, whilst T5 treatment results in the highest YS, but with some sacrifice of the elongation. It is important to observe that the solution treatment without aging (T4) provides a superior combination of elongation and UTS. In the present study, the achieved maximum UTS and elongation for the RDC AZ91D alloy were $264 \mathrm{MPa}$ and $8.1 \%$ in the as-cast state, and $278 \mathrm{MPa}$ UTS and $13.9 \%$ under the T4 treated condition.

\section{RDC process for recycling magnesium scrap}

A major challenge in recycling Mg-alloy scrap is to deal with the increased inclusions and impurity elements. In this work, we have developed a physical approach to recycling of magnesium scrap using the RDC process. Alloy melt prepared from scrap is physically treated under intensive forced convection to eliminate the detrimental effects of both inclusions and impurity elements, so that higher grade light alloy products can be produced from their scrap. Since the RDC recycled Mg-alloy has better mechanical properties than primary alloy processed by conventional technologies (e.g. the HPDC process), this new approach is termed as upcycling, which contrasts with the current concept of recycling where the scrap is converted into an existing grade of alloy often with inferior quality compared with the corresponding primary alloy grade. Compared with the conventional chemical approach to recycling, the physical approach developed here has the following advantages:

(1) Through enhanced nucleation (known as effective nucleation [13]), the primary intermetallic compounds containing impurity elements will have a much finer particle size and a compact morphology (Figure 1), resulting in improved ductility (Table 2 ). Therefore, intensive melt shearing can increase the tolerance of light alloys to impurity elements.

(2) Inclusions, such as oxide particles and oxide films, will be pulverised ( 1 to $3 \mu \mathrm{m}$ in size) and dispersed uniformly throughout the alloy matrix, becoming strengthening phases rather than detrimental factors, which in turn leads to a significant improvement of mechanical properties by elimination of stress concentration points.

(3) The RDC process can be used to produce high quality castings directly from $\mathrm{Mg}$-alloy scrap. Compared with the conventional chemical approach, it is more efficient, less energy intensive, lower in cost and has less environmental impact.

Finally, it should be pointed out that, the RDC process, as a physical approach to recycling of $\mathrm{Mg}$-alloy scrap, does have its limitations. It is more suitable for direct recycling of higher-grade scrap, such as die-cast scrap and well sorted end-of-life vehicle components. However, for lower grade scraps, such as furnace dross and old scrap mixed with other materials, the conventional chemical approaches have to be used to purify the alloy to a certain level before the RDC process can be used for direct recycling. 


\section{Gonclusions}

(1) The rheo-diecasting (RDC) process can be used to recycle high grade $\mathrm{Mg}$-alloy scrap to produce high integrity Mg-alloy castings.

(2) The RDC recycled Mg-alloy has fine and uniform microstructure with extremely low porosity.

(3) No oxide particle clusters or oxide films were found in the RDC recycled $\mathrm{Mg}$-alloy. Intermetallic compound particles containing the impurity elements have a fine size, spherical morphology and a uniform distribution in the alloy matrix.

(4) The RDC recycled AZ91D alloy has chemical compositions well within the ASTM specifications for the same alloy.

(5) The RDC recycled AZ91D alloy exhibits superior mechanical properties.

\section{Acknowledgements}

Financial support from EPSRC, UK is acknowledged with gratitude.

\section{References}

1. A. Lou, JOM, 54 (2002) 42-48.

2. H. Antrekowitsch, G. Hanko, P. Ebner, in: H.I. Kaplan (Eds.), Magnesium Technology 2002, TMS, Washington, 2002, pp. 43-49.

3. A. Javaid, E. Essadiqi, S. Bell, B. Davis, in: A.A. Luo, N.R. Neelameggham, R.S. Beals (Eds.), Magnesium Technology 2006, TMS, Texas, 2006, pp. 7-12.

4. C. Scharf, A. Ditze, in: B.L. Mordike, K.U. Kainer (Eds.), Magnesium Alloys and Their Applications, WerkstoffInformationsgesellschaft GmbH, Wolfsburg, Germany, 1998, pp. 685-690.

5. R. Lisabeth, JOM, 48 (1996) 44-46.

6. M.C. Flemings, Metall. Trans. A, 22A (1991) 957-980.

7. Z. Fan, Internat. Mater. Rev., 47 (2002) 49-85.

8. Z. Fan, M.J. Bevis, S. Ji, PCT Patent, WO 01/21343 A1, 1999.

9. Z. Fan, X. Fang, S. Ji, Mater. Sci. Eng. A, A412 (2005) 298306.

10. Z. Fan, G. Liu, Y. Wang, J. Mater. Sci., 41 (2006) 36313644.

11. Z. Fan, Mater. Sci. Eng. A, A413-414 (2005) 72-78.

12. Y. Wang, G. Liu, Z. Fan, Acta Mater., 54 (2006) 689-699.

13. Z. Fan, G. Liu, Acta Mater., 53 (2005) 4345-4537.

14. A. Balasundaram, and A.M. Gokhale, in: Magnesium Technology 2001, TMS, 2001, pp. 155-158.

15. A. Gokhale, G.R. Patel, in: Magnesium Technology 2001, TMS, 2001, pp. 195-199.

16. M.M. Avedesian, H. Baker, in: ASM Speciality Handbook Magnesium and Magnesium Alloys, ASM International, Materials Park, 1999, pp. 230-231.

17. C. Pitsaris, T. Abbott, C. Davies, G. Savage, in: K.U. Kainer (Ed.), Proc. $6^{\text {th }}$ Internat. Conf. on $\mathrm{Mg}$ Alloys and their Applications, Wiley-VCH, Weinheim, 2003, pp.694-698. 